\title{
Contraception in Adolescence: Social Necessity
}

\author{
Claribel Plain Pazos ${ }^{1 *}$, Carmen Rosa Carmona Pentón ${ }^{1}$, Anisbel Pérez de Alejo Plain², Yiset Menéndez Pedraja ${ }^{3}$, Lilian Ibonne Sosa \\ Martínez ${ }^{1,}$ Lianet Corne Sosa ${ }^{4}$ \\ ${ }^{1}$ Specialist of I and II Degree in Comprehensive General Medicine, Assistant Professor, Faculty of Medical Sciences of Sagua la Grande, Villa Clara, \\ Cuba \\ ${ }^{2} 4$ th Year Student of Medicine, Faculty of Medical Sciences of Sagua la Grande. Villa Clara, Cuba \\ ${ }^{3}$ Specialist of I Degree in Comprehensive General Medicine and Embryology, Assistant Professor, Faculty of Medical Sciences of Sagua la Grande, \\ Villa Clara, Cuba \\ 43th Year Student of Medicine, Faculty of Medical Sciences of Sagua la Grande. Villa Clara, Cuba
}

*Corresponding Author: Claribel Plain Pazos, Specialist of II Degree in Comprehensive General Medicine, Assistant Professor, Faculty of Medical Sciences of Sagua la Grande, Villa Clara,Cuba.

Received date: April 22, 2021; Accepted date: June 04, 2021; Published date: June 08,2021

Citation: Claribel P Pazos, CRC Pentón, AP Alejo Plain, Yiset M Pedraja, LIS Martínez. (2021) Contraception in Adolescence: Social Necessity. Biomedical Research and Clinical Reviews. 4(1); DOI: 10.31579/2692-9406/057

Copyright: () 2021 Claribel Plain Pazos, This is an open-access article distributed under the terms of the Creative Commons Attribution License, which permits unrestricted use, distribution, and reproduction in any medium, provided the original author and source are credited.

\section{Abstract: \\ Teenage pregnancy is a global health problem.}

The beginning of sexual life at an earlier age has an impact on the increase in sexually transmitted diseases, unwanted pregnancies, and the number of single mothers.[1]

Each year approximately 2 million adolescents under the age of 15 become pregnant[2] and an estimated 16 million girls between the ages of 15 and 19 give birth, 95\% of these births occur in developing countries. Adolescent births as a percentage of all births range from around 2\% in China to $18 \%$ in Latin America and the Caribbean.[3] The global rate of adolescent pregnancy is estimated at 46 births for every 1,000 girls and of the same Thus, the rate for Latin America corresponds to 66.5 births per 1,000 girls between the ages of 15 and 19 , ranking second worldwide, only surpassed by Sub-Saharan Africa.[4] Furthermore, complications during pregnancy and childbirth are the second leading cause of death among women 15-19 years of age worldwide.[5]

Keywords: contraception; adolescents; young women; reproductive health

\section{Introduction}

Teenage pregnancy is a global health problem.

The beginning of sexual life at an earlier age has an impact on the increase in sexually transmitted diseases, unwanted pregnancies, and the number of single mothers [1].

Each year approximately 2 million adolescents under the age of 15 become pregnant [2] and an estimated 16 million girls between the ages of 15 and 19 give birth, $95 \%$ of these births occur in developing countries. Adolescent births as a percentage of all births range from around $2 \%$ in China to $18 \%$ in Latin America and the Caribbean [3]. The global rate of adolescent pregnancy is estimated at 46 births for every 1,000 girls and of the same Thus, the rate for Latin America corresponds to 66.5 births per 1,000 girls between the ages of 15 and 19, ranking second worldwide, only surpassed by Sub-Saharan Africa [4]. Furthermore, complications during pregnancy and childbirth are the second leading cause of death among women 15-19 years of age worldwide [5].

In Cuba, in the last five years, the fertility rate for adolescents between the ages of 15 and 19 has remained at around $50 \times 1000$ women of this age range. 6 An estimated 38 million adolescents are sexually active. About 15 million of these use some modern contraceptive method; the remaining 23 million have an unmet need for modern contraceptives and are therefore at risk of unintended pregnancy [2].

There is evidence that indicates that a high proportion of teenage pregnancies are not wanted, $[3,4,7]$ for which reason some adolescents choose to interrupt it, often in unsafe conditions [7].

Some adolescent girls do not know how to avoid pregnancy, as in many countries there is no sex education [6]. In developing countries, about 225 million women want to postpone or stop childbearing but do not use any contraceptive method [3].

Despite advances in contraceptive technology, and the greater availability of birth control measures, many adolescents become pregnant without prior planning, and without having previously used any contraceptives [8]. Despite the fact that the majority of adolescents have knowledge about contraception, the use of these methods is still low [9].

Pregnancy and motherhood in adolescence are phenomena that affect the sexual health, reproductive health and well-being of young women, their families and communities, as well as the development of a country, given the multiple effects in the health fields physical, psychosocial and in the political, economic and social fields that interfere not only in the quality 
of life and health of adolescents and their families, but also of society, which implies that there is school dropout [3].

Access to contraceptive methods is essential to achieve the well-being and autonomy of women, and in adolescence, in particular, it is of vital importance as a measure for birth control.

Adolescence is defined by the period of human growth and development that occurs after childhood and before adulthood, between the ages of 10 and 19. It is one of the most important transition stages in human life, characterized by an accelerated rate of growth and changes $[1,4,5]$. This is a period of growth not only biological but also psychological and social

The early initiation of sexual relations without having the fundamental bases to carry out this responsibility, tends to cause unfavorable results where the health of adolescents is put at risk. A key factor in reducing the number of unplanned pregnancies and sexually transmitted infections is the use of contraceptive and barrier methods. However, one of the main reasons why young people do not use contraceptive methods is inadequate sexuality education, given that many families do not talk about sexuality and adolescents sometimes receive the wrong information [10].

This problem intensifies in countries and families where low socioeconomic levels predominate. There are still countries where sexuality is taboo, and adolescents do not receive training of any kind on the subject.

Contraceptive methods are means that temporarily and reversibly prevent or reduce the possibility of a return to fertilization after stopping the use of a contraceptive method and of a pregnancy occurring during sexual intercourse. It generally involves actions, devices or medications in which each one has its level of effectiveness; For this reason, each couple is free to choose a method according to their preferences [11]. This depends, many times, on the availability of the same in the market and the purchasing power available. Adolescents often have to use contraceptive methods that are not desired due to the lack of availability of the one chosen by them.

Teenagers can use any method of contraception; age is not a sufficient reason to advise neither [1]. The choice of a contraceptive method requires careful medical advice [12]. The social and behavioral aspects of adolescents must be considered when recommending a method [1]. Sex is a variable It is also important when selecting a contraceptive method, as currently there are methods for both sexes.

According to acceptability, contraceptive methods in adolescence can be classified into: recommended / preferred: condom, combined hormonal contraception (oral, transdermal and vaginal ring), gestagen-only oral hormonal contraception and intrauterine device (IUD). Acceptable: hormonal depot contraception (injectables and implants) or diaphragm. Not very acceptable: natural methods and surgical contraception. Emergency: postcoital contraception [12].

Although no contraceptive method is $100 \%$ effective, it increases when more than one method is used at the same time.

At the international level, dual contraceptive protection has been promoted to prevent both pregnancies and sexually transmitted infections; This includes the joint use of a condom and some modern contraceptive method (CAM), in particular, long-acting reversible (ARAP), which are the most cost-effective, and as they do not require daily adherence or maintenance, they have high acceptance among adolescent girls [13].

The promotion of the use of condoms as a contraceptive method in adolescence should be a worldwide policy, since instability in sexual relations is frequent at this age, as well as the frequent change of sexual partners, and this method has the particularity that In addition to protecting against an unwanted pregnancy, it also protects against the acquisition of sexually transmitted diseases.

Despite the use of modern contraceptive methods, fears always arise in the population about possible adverse effects such as: sterility, congenital malformations and harm to women, this limits a greater use of contraceptives in women who have unmet needs [1]. It is necessary If the fears referred by adolescents are clarified, it is not enough to get adolescents to use contraceptive methods sporadically, it is necessary to achieve frank adherence to them.

In several studies carried out on the contraceptive methods known to adolescents, it was found that the vast majority had knowledge about them, $[1,3,8,10,12,14]$ however, in some studies, less than $50 \%$ implemented its use in the first sexual intercourse. 1 In relation to the most used method, several authors agreed on selecting the condom and / or tablets as the most widely used contraceptive method, [1,7,10-15] although there are other studies that reveal the use of the condom in a very small part of adolescents.[8] While in an analysis of the contraceptive methods used according to sex, it was observed that in males the most frequently used method was the condom while in females it was contraceptive tablets $[9,14,16]$. Although on some occasions despite the fact that these methods are used by adolescents, they do not use them correctly $[7,10,15]$.

It was also found that the most important sources of information on the subject were: the family, the media and the health professional [15].

The level of knowledge that adolescents have about contraceptive methods is not related to their use, [11] although the literature shows that the use of contraceptives from the beginning of sexual life is associated with a greater possibility of consistent use [13, 17].

Sex education in adolescence and sexual and reproductive health programs are not only a biological but also a social necessity, with which adolescents are provided with the necessary information about modern contraceptive methods, as well as how to access their use.

\section{References}

1. Balladares Avendaño AS, Duarte Acevedo JN, Fley Sosa EE. (2017) Conocimientos, actitudes y prácticas sobre métodos anticonceptivos en adolescentes embarazadas ingresadas en las casas maternas del municipio de Waslala en el primer trimestre del 2016 (Doctoral dissertation, UNIVERSIDAD NACIONAL).

2. Marquina Alfaro KL, Méndez Laureano DN. (2021) Nivel de conocimiento y actitudes hacia el uso de métodos anticonceptivos en adolescentes.

3. Acosta Rodriguez AL. (2018) Estrategias educativas en planificación familiar para la prevención de embarazos en adolescentes de la Unidad Educativa Tulcán (Bachelor'sthesis).

4. Organizacion Panamericana de Salud. (2018) América Latina y el Caribe tienen la segunda tasa más alta de embarazo adolescente en el mundo.

5. Marino Collado JP. (2017) Nivel de conocimiento y uso de métodos anticonceptivos en adolescentes de 13 a 19 años de edad del colegio y academia del grupo Joule Arequipa 2017.

6. Dirección Nacional de Registros Médicos y Estadísticos de Salud. (2020) Anuario Estadístico de la Salud 2019. La Habana: Ministerio de Salud Pública.

7. Zamberlin N, Keller V, Rosner M, Gogna M. (2017) Adopción y adherencia al uso de métodos anticonceptivos posevento obstétrico en adolescentes de 14-20 años. Revista Argentina de Salud Pública. 8(32): 26-33.

8. Silva MA, José M, Reasco ME, Maffare MV. (2018) Uso de Métodos Anticonceptivos por las Adolescentes que Acuden al 
Centro de Salud del Área No. 2 de la Ciudad de Esmeraldas. Revista Científica Hallazgos.

9. Carmona G, Beltran J, Calderón M, Piazza M, Chávez S. (2017) Contextualización del inicio sexual y barreras individuales del uso de anticonceptivos en adolescentes de Lima, Huamanga e Iquitos. Revista Peruana de Medicina Experimental y Salud Pública. 34: 601-610.

10. Ortiz ML, Barrios Ortega A, Chávez Cruz A, Molina LAJ, Omaña Hernández M, Padilla MLS. Intervención educativa sobre métodos anticonceptivos en adolescentes. Educación y Salud Boletín Científico Instituto de Ciencias de la Salud Universidad Autónoma del Estado de Hidalgo. 8(16): 116-122.

11. Tamay DMU, Asenjo Alarcón JA. (2020) Conocimiento y uso de métodos anticonceptivos en adolescentes de colegios estatales. Revista científica CURAE [Internet]. [citado 2021 Mar 19]; 3(2): 16-25.

12. Carpio XL. (2020) Conocimiento de métodos anticonceptivos en estudiantes adolescentes. Revista Vive. 3(7): 17-26.

13. Villalobos A, Ávila Burgos L, Hubert C, Suárez López L, de la Vara Salazar E, Hernández Serrato MI, Barrientos Gutiérrez T.
(2020) Prevalencias y factores asociados con el uso de métodos anticonceptivos modernos en adolescentes, 2012 y 2018. salud pública de méxico 648-660.

14. Suares Villa M, Lastrea Amell G, Rodríguez López J. (2021) El conocimientos y prácticas en salud sexual y reproductiva en estudiantes universitarios de Barranquilla Colombia. Identidad Bolivariana. 5(1):18-32.

15. Gómez PS, Bolatti VB. (2021) La participación de varones y mujeres jóvenes en la toma de decisiones sobre salud sexual y reproductiva en Argentina: género y asimetrías socioeconómicas. Población y Salud en Mesoamérica.

16. Gómez, P. S., Bolatti, V. B. (2021). La participación de varones y mujeres jóvenes en la toma de decisiones sobre salud sexual y reproductiva en Argentina: género y asimetrías socioeconómicas. Población y Salud en Mesoamérica.

17. Villalobos A, de Castro F, Rojas R, Allen B. (2017) Anticoncepción en adolescentes mexicanos de escuelas del nivel medio superior: uso y necesidades insatisfechas. Salud Pública Mex. 59:566-576.
This work is licensed under Creative Commons Attribution 4.0 License

\section{To Submit Your Article Click Here: Submit Manuscript}

DOI: $10.31579 / 2692-9406 / 057$
Ready to submit your research? Choose Auctores and benefit from:

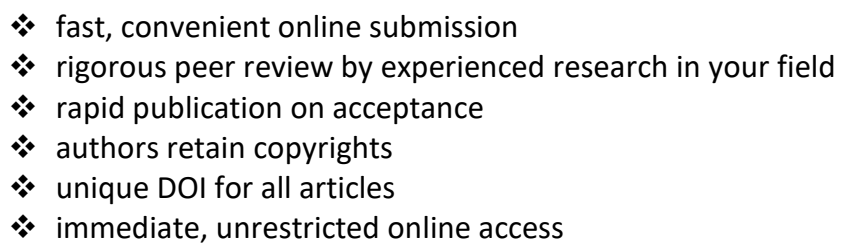

At Auctores, research is always in progress.

Learn more www.auctoresonline.org/journals/journal-of-clinical-andlaboratory-research- 